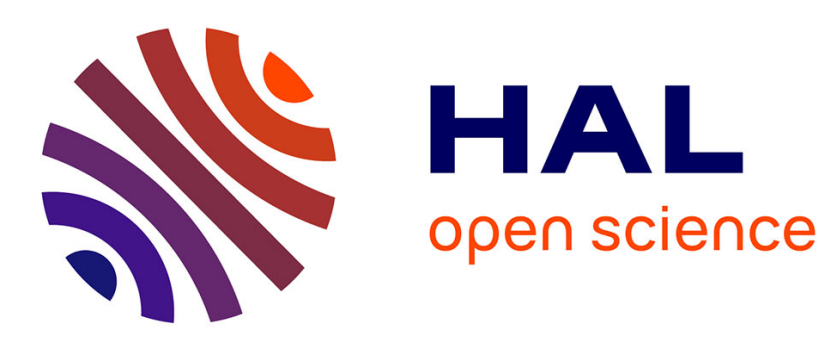

\title{
Demographic Patterns Distinctive of Epidemic Cemeteries in Archaeological Samples
}

Dominique Castex, Sacha Kacki

\section{To cite this version:}

Dominique Castex, Sacha Kacki. Demographic Patterns Distinctive of Epidemic Cemeteries in Archaeological Samples. Microbiology Spectrum, 2016, 4 (4), pp.PoH-0015-2015. 10.1128/microbiolspec.PoH-0015-2015 . hal-03140760

\section{HAL Id: hal-03140760 \\ https://hal.science/hal-03140760}

Submitted on 13 Feb 2021

HAL is a multi-disciplinary open access archive for the deposit and dissemination of scientific research documents, whether they are published or not. The documents may come from teaching and research institutions in France or abroad, or from public or private research centers.
L'archive ouverte pluridisciplinaire $\mathbf{H A L}$, est destinée au dépôt et à la diffusion de documents scientifiques de niveau recherche, publiés ou non, émanant des établissements d'enseignement et de recherche français ou étrangers, des laboratoires publics ou privés. 


\title{
Demographic Patterns Distinctive of Epidemic Cemeteries in Archaeological Samples
}

\author{
DOMINIQUE CASTEX and SACHA KACKI \\ UMR 5199 du CNRS, PACEA, Anthropologie des Populations Passées et Présentes, Pessac, France
}

\begin{abstract}
The analysis of biological parameters such as age and sex is particularly relevant to the interpretation of ancient skeletal assemblages related to abrupt mortality crises, and more particularly epidemics. In such a context, the mechanisms of selection within a population or part of a population differ according to the pathogen involved. They may also vary depending on the period and location in which the population lived. Here, we illustrate the specificity of plague mortality through the study of several European burial sites contemporary with the first and second plague pandemics. The paleodemographic patterns obtained for different plague outbreaks from the 6th to the 16th centuries reveal some constant features over time and space as well as some differences that suggest a possible evolution in the epidemiological characteristics of the disease.
\end{abstract}

Some ancient burial grounds are valuable testimonies of past epidemics. For both funerary archaeologists and paleobiologists, such archaeological sites offer a remarkable research framework to reveal unfamiliar aspects of these historical events, especially those that occurred during periods for which very few or no written sources exist. The multiplicity of congresses, articles, and syntheses on this topic in recent years illustrates the interdisciplinary research that has progressively emerged over the past two decades.

The detection of an ancient mortality crisis generally relies on archaeological evidence such as mass graves - that is, pits where numerous bodies were buried at the same time (1). However, retaining the hypothesis of an epidemic crisis also requires some paleobiological investigations. First of all, a careful examination of the skeletal remains must be undertaken to make sure that they do not exhibit any traumatic lesions evocative of violent death. Such stigmata would be expected in the case of mass graves related to war or massacre, so that their absence favors the epidemic hypothesis. However, a paleopathogical study cannot demonstrate an epidemic context because the highly virulent pathogens involved kill individuals before any skeletal lesion can develop. Other methods of analysis are therefore needed to ascertain the precise nature of an epidemic. Besides paleomicrobiological studies, analysis of the age and sex composition of skeletal assemblages can provide some valuable arguments. Indeed, the ageand sex-specific mortality rates within a population or part of a population at a given time and place may differ depending on the pathogen involved. The study of these biological parameters is particularly relevant to a discussion of the cause of an epidemic mortality crisis.

The scope of this article is voluntarily limited to the demographic analysis of burial grounds related to plague epidemics. Through the study of several of these sites, we illustrate the specificities of mortality by age and sex in such a context. We also discuss some demographic differences between several epidemic outbreaks.

\section{MATERIALS AND METHODS}

This work is based on a study of seven European burial sites of plague victims (Fig. 1). With the exception of the Hereford site, all of these burial grounds were used exclusively to bury the victims of plague epidemics. We therefore included in the analysis every skeleton recovered, whether from individual burials or multiple burials. For the Hereford cemetery, which was also used out of the epidemic context over a long period, we studied only the skeletons recovered from three multiple burials, which were proved to be the skeletons of the victims of a plague epidemic. 
Two of the sites investigated (Sens and Poitiers) are contemporaneous with the first plague pandemic, known as Justinian's plague. This pandemic began in the 6th century and continued intermittently in Europe until the mid-8th century. Three other sites (Dreux, Hereford, and Barcelona) are contemporaneous with the Black Death-that is, the first outbreak of the second plague pandemic in the mid-14th century. Plague then waxed and waned in Europe until the late 18th century, and the last two sites we analyzed (Les Fédons and Dendermonde) are related to resurgences of the disease at the end of the 16th century. For every one of these archaeological burial grounds (Fig. 2), the cause of death is attested to by historical sources (Poitiers, Dendermonde) or by DNAanalysis (Sens, Dreux, Hereford, Barcelona, Les Fédons).

The first step of the study of each site was to estimate the age at death and determine the sex of all the exhumed individuals by using reliable skeletal indicators (for a critical review of current methods and their application, see reference 8). Estimation of the age at death of non-adults was based primarily on the degree of dental maturation (9-11). When teeth were absent or fully mineralized, we additionally considered the diaphyseal length of the long bones (12) and the stage of fusion of secondary ossification enters $(13,14)$. Sex determination was carried out only for adult individuals, with reliance primarily on the morphoscopic and morphometric characteristics of the hip bones $(15,16)$. In order to reduce the number of individuals whose sex possible, a secondary sex determination based on the extrapelvic dimorphism of each skeletal assemblage (17). These data were then used to define the composition of the population as well as possible. The mortality profile and the rate of masculinity (i.e., ratio of the number of men to the number of men and women) of each skeletal assemblage were critically discussed within the framework of a comparative analysis, with reliance on historical data and various standard life tables. Data were compared with an archaic/pre-Jennerian mortality pattern, with the variability of mortality and the confidence intervals of the probabilities of death taken into account. The model life tables of Ledermann (18) were used to make the comparisons. Such an approach has an objective distinct from those of traditional paleodemographic analyses, as it does not aim to determine the demographic characteristics of living populations (e.g., life expectancy at birth, average age at death) but rather to detect anomalous demographic patterns that can be interpreted as evidence of burial selection or abnormal mortality (2). If one assumes that the reference pattern(s) reflect a "natural" demography (i.e., deaths over a long period of time with no majormortality crises), the discrepancies between the reference and the paleodemographic data can reflect change in mortality parameters due to a peculiar event.

Given the poor accuracy of the methods of estimating adult age from the skeleton (8), mortality profiles were analyzed only for immature subjects. As in the model life tables used for comparison, the immature individuals were distributed into 5-year groups (apart from the first two groups, which were 1and 4-year groups) of attained age. The mortality profile of the subjects from each site was then established by calculating the mortality quotients (Table 1 ) and was compared with the theoretical mortality pattern (18). The mortality quotient takes the form aQx, where $\mathrm{x}$ is the age of entry into an age group and $\mathrm{a}$ is the duration in years of the age group. aQx is the ratio of the number of people in an age group who die to the number of people alive at the start of that age group. It thus represents the probability of dying within a precise period of life. It differs from the rate of death, which is the proportion of deaths within an average population. The mortality quotient is more pertinent for comparing a theoretical natural mortality with the mortality profile obtained from an archaeological sample. The life tables of Ledermann (18) allow calculation of the $95 \%$ confidence interval of the mortality quotients (illustrated by a range of values in the graphs). The model life tables used in the current study are for a life expectancy at birth ranging from 25 to 35 years; these parameters lie between the 20 - and 40 -year life expectancy range that characterizes known pre-Jennerian populations $(19,20)$.

Rates of masculinity were calculated only for adults, as there is currently no reliable method of sex determination for sub-adults. Values were compared with a theoretical rate of $50 \%$.

\section{DEMOGRAPHIC CHARACTERISTICS OF THE PLAGUE BURIAL SITES}

The results described below point out the demographic characteristics of each site. Comparisons among the sites reveal similarities in mortality profiles specific for plague mortality, as well as some inter-site differences. 


\section{Proportion of Immature Individuals}

According to the model life tables of Ledermann (18), the proportion of immature individuals in an archaic population theoretically ranges from $45 \%$ to $64 \%$, for a life expectancy at birth of between 25 and 35 years. The values in the skeletal assemblages show some variation(Fig. 3). For three of the sites, the proportions recorded are compatible with the one expected in a context of natural mortality. For the four other sites, the values are slightly above the theoretical range. There is a small deficit of subjects who died before 20 years of age.

At first sight, the proportion of non-adults appears more important over time, from the first wave of Justinian's plague in the 6th century to the resurgences of the second pandemic in the 16th century. However, two sites from the 14th century (Hereford and Barcelona) differ from this general pattern. The differences in the proportion of immature individuals for the same time period may reflect geographical variations in the epidemiological characteristics of plague, resulting in a lower mortality rate in the youngest in Barcelona (41.7\%) or a higher rate in Dreux (50.7\%). However, we cannot exclude a potential bias that would have led to an underestimation of the number of immature individuals in the English and Spanish sites.

Two important biases can be mentioned. The first one concerns the Hereford cemetery. For this site, only individuals from mass graves were taken into account. Several studies have demonstrated that various burial methods were adopted during epidemics and that single graves may coexist with mass graves $(6,21)$. Thus, a consideration of only mass graves may yield misleading results. The second bias concerns the plague pit of Barcelona. Several of the 120 recovered skeletons consisted only of lower limb bones and were categorized as probable adults according the bone dimensions. This arbitrary choice may have resulted in an underestimation of the number of adolescents and consequently of the number of immature individuals as a whole.

Based on the data currently available, the lowest representation of non-adults in the most recent plague burial sites deserves to be pointed out but cannot be interpreted as clear evidence of an evolution of plague epidemiological characteristics. Further studies would be needed to reach a conclusion on this question.

\section{Mortality Quotients by Age Groups}

The mortality profiles were established by calculating the mortality quotients for all age groups. They were then compared with a theoretical mortality model (18). Regardless of their chronology, the skeletal assemblages show recurrent anomalies (Fig. 4). In each case, there is a deficit in the number of children younger than 5 years of age. The infantile (younger than 1 year) mortality quotient and the mortality quotient of the 1- to 4-year age group are low in comparison with those characterizing a natural mortality. The most significant deficit affects the first age group. Whatever the site, the mortality quotient values of children younger than 1 year of age never exceed $30 \%$, whereas the theoretical values range from $156.3 \%$ to $459.8 \%$. For the two sites linked to Justinian's plague (Sens and Poitiers), infants are totally missing (Fig. 4a).

The relative constancy of the infantile mortality quotient values suggests that this deficit is specific to plague mortality. We cannot ignore that a cultural bias may have contributed to this anomaly, as very young children may have been buried in places other than the plague cemeteries. However, the anomaly is so recurrent that it is more likely that it is a distinguishing demographic characteristic of plague. This particularity should be investigated further in future research.

The mortality quotient of the 1- to 4-year age group is such more variable. Its value should range between $116.9 \%$ and $607.6 \%$. It is considerably lower for the two sites contemporaneous with Justinian's plague and for the Dendermonde cemetery, whereas it is close to the lower boundary of the theoretical interval for Barcelona, Hereford, and Les Fédons and has a median value for Dreux. Except for the last site, this mortality quotient never exceeds $147.3 \%$.

Conversely, the mortality quotients in the 5- to 9-year, 10- to 14-year, and 15- to 19-year age groups are noticeably higher than expected. Moreover, the proportions of individuals in all of these three age groups differ from the proportion for a natural mortality, which is characterized by a minimum number of deaths in the 10- to 14-year age group. These anomalies are obvious on the mortality profiles. The over- 
representation of older children and adolescents is also clearly demonstrated by the high values of the juvenility index ( $\left.\mathrm{D}_{5-14} / \mathrm{D}_{20+}\right)$, which systematically exceed the range of 0.1 to 0.3 expected in an archaic mortality pattern (22). The juvenility indices are notably similar for plague burial sites from the 6 th and 14th centuries, with values between 0.37 and 0.47 (Table 1). This anomaly is much more pronounced for the 16th century sites, which have very high juvenility indices.

Numerous individuals between the ages of 15 and 9 years also died. Although the mortality quotients for this age group vary depending on the sites, the values obtained are systematically close to the upper boundary of the theoretical interval (Hereford, Les Fédons) or far beyond it. This systematic surplus reveals that older adolescents were not spared during plague epidemics. No differences were observed according to the chronology of the epidemics.

To summarize all these results, the age composition of the skeletal samples from plague burial sites clearly differs from the one expected in a non-epidemic context in two main respects: an underrepresentation of very young infants and a high number of deaths in individuals between the ages of 5 and 14 years. This conclusion confirms those of previous studies by showing a specific mortality profile that mimics the age structure of the living population (2). The current study, however, reveals how these demographic features vary from site to site and according to epidemic cycles. These new data open perspectives to be explored in future studies.

\section{Adult Sex Distribution}

At the level of the entire corpus, the sex proportions do not differ significantly from a theoretical masculinity rate of $50 \%$. There are, however, some peculiarities according to the funerary site considered (Fig. 5). Two skeletal assemblages from the 14th century (Hereford and Dreux) are characterized by a larger proportion of females (masculinity rates of $43.5 \%$ and $42.3 \%$ respectively), whereas in others the sex ratios are more balanced. The disparity between the masculinity rate and its theoretical value is more important for the sites related to the Black Death than in those related to Justinian's plague and to the resurgences of the second pandemic; however, it must be stressed that the number of individuals whose sex could be determined is relatively small. Thus, there is no strong argument to conclude that there was a preferential female mortality during the 14th century plague epidemics. Given that the differences between the observed and theoretical masculinity rates are never significant, it seems that plague did not kill discriminately with respect to the sex of individuals.

\section{DEMOGRAPHIC SPECIFICITIES OF THE PLAGUE}

The study of seven burial sites related to plague revealed many similarities in the age and sex composition of the skeletal samples, which differ in some respects from those expected in a context of natural mortality. The results strongly reinforce those of previous anthropological studies $(2,23,24,25)$. The opportunity to analyze a large number of plague burial sites from different time periods has allowed a finer analysis of the demographic repercussions of the disease. This study reasonably supports that a demographic signature existed characterizing plague mortality, irrespective of chronological and geographical contexts. Its main characteristics are as follows:

1. mortality quotient for individuals younger than 20 years compatible with that for a natural mortality;

2. deficit of young children, particularly noticeable for individuals younger than 1year;

3. excessive number of individuals between 5 and 14 years of age (high juvenility index);

4. over-representation of the oldest adolescents (15 to 19 years);

5. balanced sex ratio.

Despite these characteristics common to the sites, it is noteworthy that there are also some differences between sites. Minor variations may be ascribed to differences in the biological composition of the living populations. Others can be linked to methodological issues resulting, for example, from poor bone preservation or from incomplete recovery of skeletons due to partial excavation of the sites.

In contrast, some differences seem to be linked to the chronology of the funerary sites. The most significant one concerns the number of individuals in the 5- to 14-year age group. The extent to which they are overrepresented varies considerably according to chronology. The anomaly is moderate during Justinian's plague and the Black Death, whereas it is much more pronounced during the resurgences of the 
second pandemic. The reason for these differences cannot be readily explained. There are currently few sites available for each period. Part of the explanation may perhaps be found in the biological composition of the human groups affected, in which individuals may already have been selected according to age. Another hypothesis is that the demographic impact of plague changed over time as the result of a modification in the virulence of Yersinia pestis and/ or changes in the vulnerability of the human population to the disease.

\section{CONCLUSIONS}

By using adapted methodology and tools, paleobiologists can analyze the age and sex composition of an archaeological population and reveal its demographic particularities. Such an approach is extremely valuable in the interpretation of epidemic mortality crises, as it can provide arguments on which to base a discussion of the nature of the disease. As illustrated herein, it is possible to distinguish among different "anomalous demographic patterns" a specific plague mortality profile. The increasing number of burial sites now available makes it possible to explore new lines of research, such as tracking a possible evolution in the demographic signature of plague epidemics over centuries. The interpretation of such slight variations in the mortality profiles, however, will be possible only through the study of many more plague cemeteries all over Europe that are of various chronologies.

ACKNOWLEDGMENTS: This research has been funded by a grant from the Maison des Sciences de l'Homme d'Aquitaine (projet Région Aquitaine) and by a ministerial grant from the French Research National Agency (program of investments for the future, grant ANR-10-LABX- 52). The anthropological study of the burials sites referred to in the paper was conducted as part of the research for a Ph.D. thesis (S.K.) and as academic research (D.C.). S.K. is grateful to the institutions that provided access to the skeletal material from Hereford (Bradford Archaeological Research Centre, Bradford, United Kingdom), Barcelona (Museu d'Historia de Barcelona, Spain), Les Fédons (UMR 7268 - ADES, Marseille, France), and Dendermonde (Royal Belgian Institute of Natural Sciences, Brussels, Belgium).

\section{REFERENCES}

1. Castex D, Kacki S, Réveillas H, Souquet-Leroy I, Sachau-Carcel G, Blaizot F, Blanchard P, Duday H. 2014. Revealing archaeological features linked to mortality increases. Anthropologie (Brno) 52:299-318.

2. Castex D. 2008. Identification and interpretation of historical cemeteries linked to epidemics, p 23-48. In Raoult D, Drancourt M (ed), Paleomicrobiology: Past Human Infections. Springer-Verlag, Berlin, Germany. 3. Godo C. 2010. Les inhumations intra-muros de Poitiers entre le IVe et le VIle s. Biologie, gestes funéraires et essai d'interprétation. Master thesis. University of Nanterre, Paris, France

4. Stone R, Appleton-Fox N. 1996. A view from Hereford's past: a report on the archaeological excavation in Hereford Cathedral Close in 1993. Logaston Press, Hereford, UK.

5. Kacki S, Castex D. 2014. La sépulture multiple de la basilique des Saints Martyrs Just et Pastor : bioarchéologie des restes humains. Quaderns d'Arqueologia i História de la Ciutat de Barcelona. 10:180-199.

6. Bizot B, Castex D, Reynaud P, Signoli M. 2005. La saison d'une peste (avril-septembre 1590). Le cimetière des Fédons à Lambesc. CNRS Éditions, Paris, France.

7. Kacki S. 2016. Influence de l'état sanitaire des populations anciennes sur la mortalité en temps de peste : contribution à la paléoépidémiologie. PhD thesis. University of Bordeaux, Bordeaux, France.

8. Bruzek J, Schmitt A, Murail P. 2005. Identification biologique individuelle en paléoanthropologie. Détermination du sexe et estimation de l'âge au décès à partir du squelette, p 217-246. In Dutour O, Hublin $\mathrm{JJ}$, Vandermeersch B (ed), Origine et évolution humaine. Comité des Travaux Historiques et Scientifiques, Paris, France.

9. Moorrees CFA, Fanning EA, Hunt EE. 1963a. Age variation of formation stages for ten permanent teeth, J Dent Res 42:1490-1502.

10. Moorrees CFA, Fanning EA, Hunt EE. 1963b. Formation and resorption of three deciduous teeth in children, Am J Phys Anthropol 21:205-213. 
11. Ubelaker DH. 1978. Human Skeletal Remains: Excavation, Analysis, Interpretation. Aldine, Chicago, IL. 12. Maresh MM. 1970. Measurements from roentgenograms, p 157-200. In McCammon RW (ed), Human Growth and Development. Charles C. Thomas, Springfield, IL.

13. Scheuer L, Black S. 2000. Developmental Juvenile Osteology. Elsevier Academic Press, London, UK.

14. Coqueugniot H, Weaver TD, Houët F. 2010. Brief communication: a probabilistic approach to age estimation from infracranial sequences of maturation. Am J Phys Anthropol 142:655-664.

15. Bruzek J. 2002. A method for visual determination of sex, using the human hip bone. Am J Phys Anthropol 117:157-168.

16. Murail P, Bruzek J, Houët F, Cunha E. 2005. DSP: a tool for probabilistic sex diagnosis using worldwide variability in hip-bone measurements. Bulletins et Mémoires de la Société d'Anthropologie de Paris 17:167176.

17. Murail P, Bruzek J, Braga J. 1999. A new approach to sexual diagnosis in past populations. Practical adjustments from Van Vark's procedure. Int J Osteoarchaeol 9:39-53.

18. Ledermann S. 1969. Nouvelles tables-types de mortalité. INED, PUF (Travaux et Documents, 53), Paris, France.

19. Masset C. 1975. La mortalité préhistorique, p 63-90. In Cahiers du Centre de Recherches Préhistoriques, Université de Paris I, 4. University of Paris, Paris, France.

20. Sellier P. 1996. Lamise en évidence d'anomalies démographiques et leur interprétation: population, recrutement et pratiques funéraires du tumulus de Courtesoult, p 188-200. In Piningre JF (ed), Le tumulus de Courtesoult (Haute-Saône) et le ler Age du Fer dans le Bassin Supérieur de la Saône. Éditions de la Maison des Sciences de l'Homme (DAF), Paris, France.

21. Kacki S, Castex D, with collaboration of Cabezuelo U, Donat R, Duchesne S, Gaillard A. 2012. Réflexions sur la variété des modalités funéraires en temps d'épidémie. L'exemple de la Peste noire en contextes urbain et rural. Archéologie Médiévale 42:1-21.

22. Bocquet J-P, Masset C. 1977. Estimateurs en paléodémographie. L'Homme 17:65-90.

23. Margerison BJ, Knüsel CJ. 2002. Paleodemographic comparison of a catastrophic and an attritional death assemblage. Am J Phys Anthropol 119:134-148.

24. Gowland RL, Chamberlain AT. 2005. Detecting plague: palaeodemographic characterisation of a catastrophic death assemblage. Antiquity

79:146-157.

25. Signoli M. 2006. Études anthropologiques des crises démographiques en contexte épidémique: aspects paléo- et biodémographique de la peste en Provence. Archaeopress (British Archaeological Reports, International Series, 1515), Oxford, UK. 
Fig. 1. Names and locations of the seven European burial sites used for the demographic analysis.

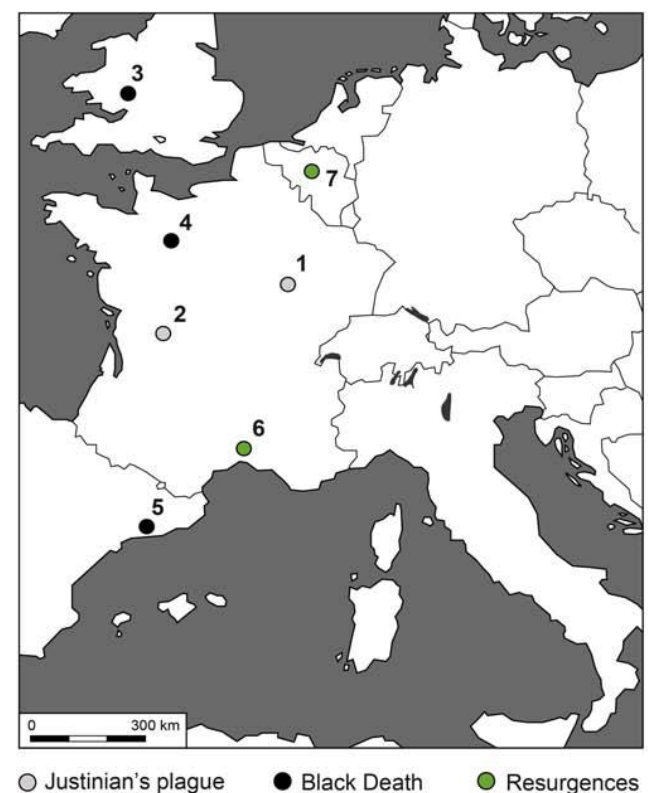

\begin{tabular}{|lcc}
\hline Sites & Chronology & References \\
\hline 1 - Sens (France) & 6th c. & $\underline{2}$ \\
2 - Poitiers (France) & 6th c. & $\underline{3}$ \\
3 - Hereford (England) & 14 th c. & $\underline{4}$ \\
4 - Dreux (France) & 14th c. & $\underline{2}$ \\
5 - Barcelona (Spain) & 14th c. & $\underline{5}$ \\
6 - Les Fédons (France) & 16th c. & $\underline{6}$ \\
7 - Dendermonde (Belgium) & 16th c. & $\underline{7}$ \\
\hline
\end{tabular}

Fig. 2. Examples of burials with simultaneous deposits (i.e., mass graves): Poitiers, Poitou-Charentes, France (a); Dreux, Eure-et-Loir, France (b); Dendermonde, Belgium (c).

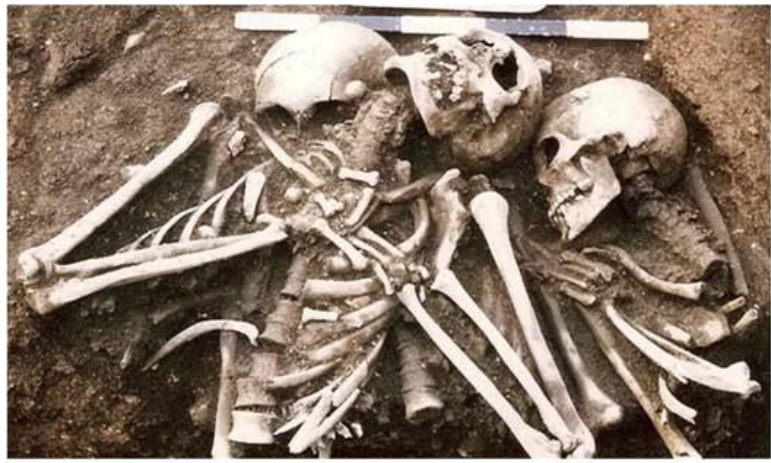

A

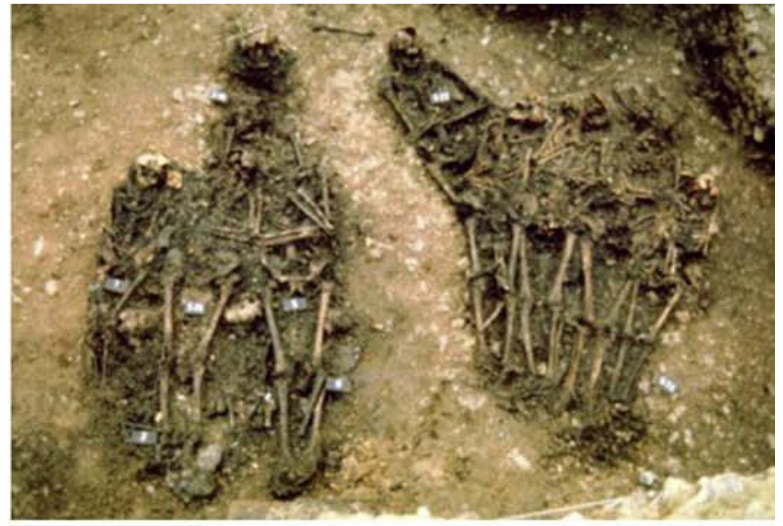

B

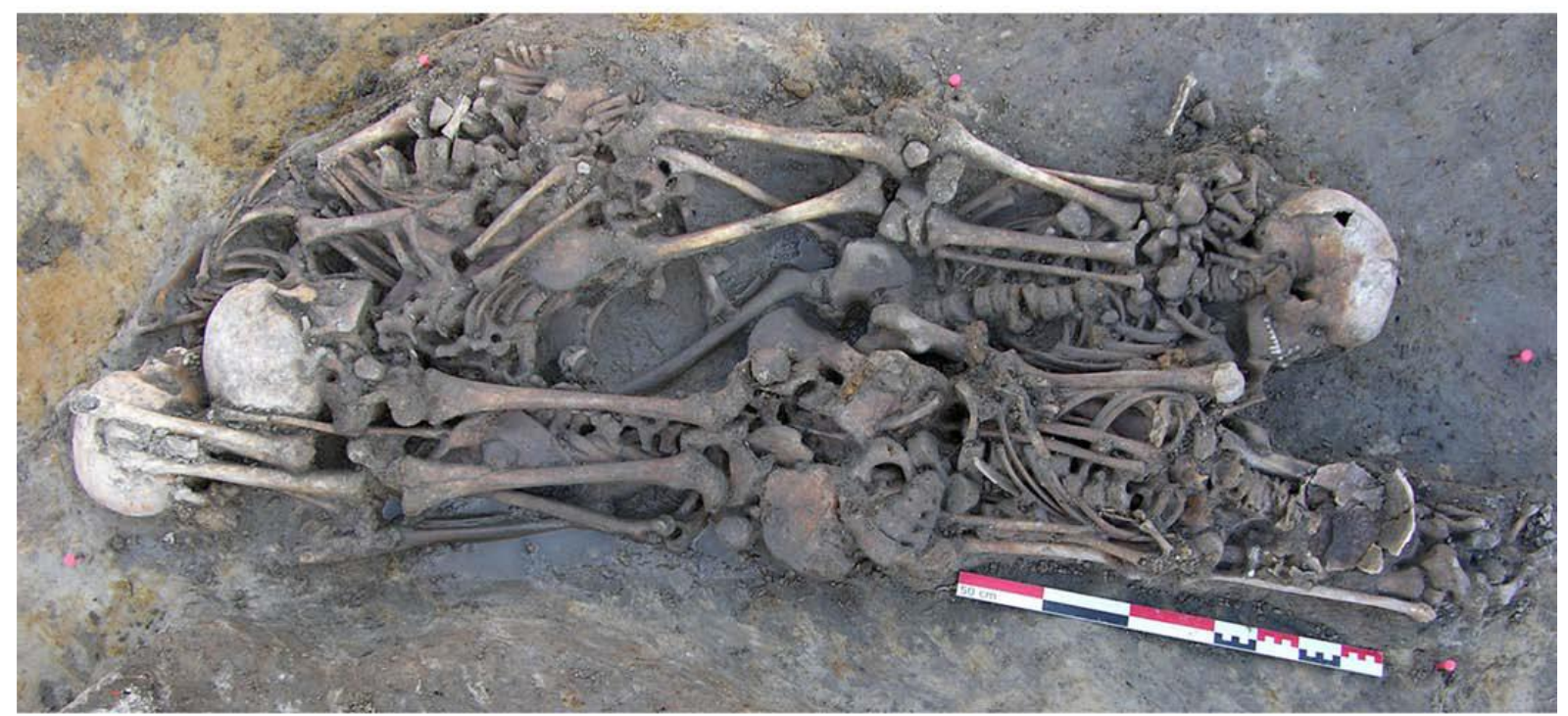

C 
Fig. 3. Proportion of non-adults for each plague site.

Non-adults Adults

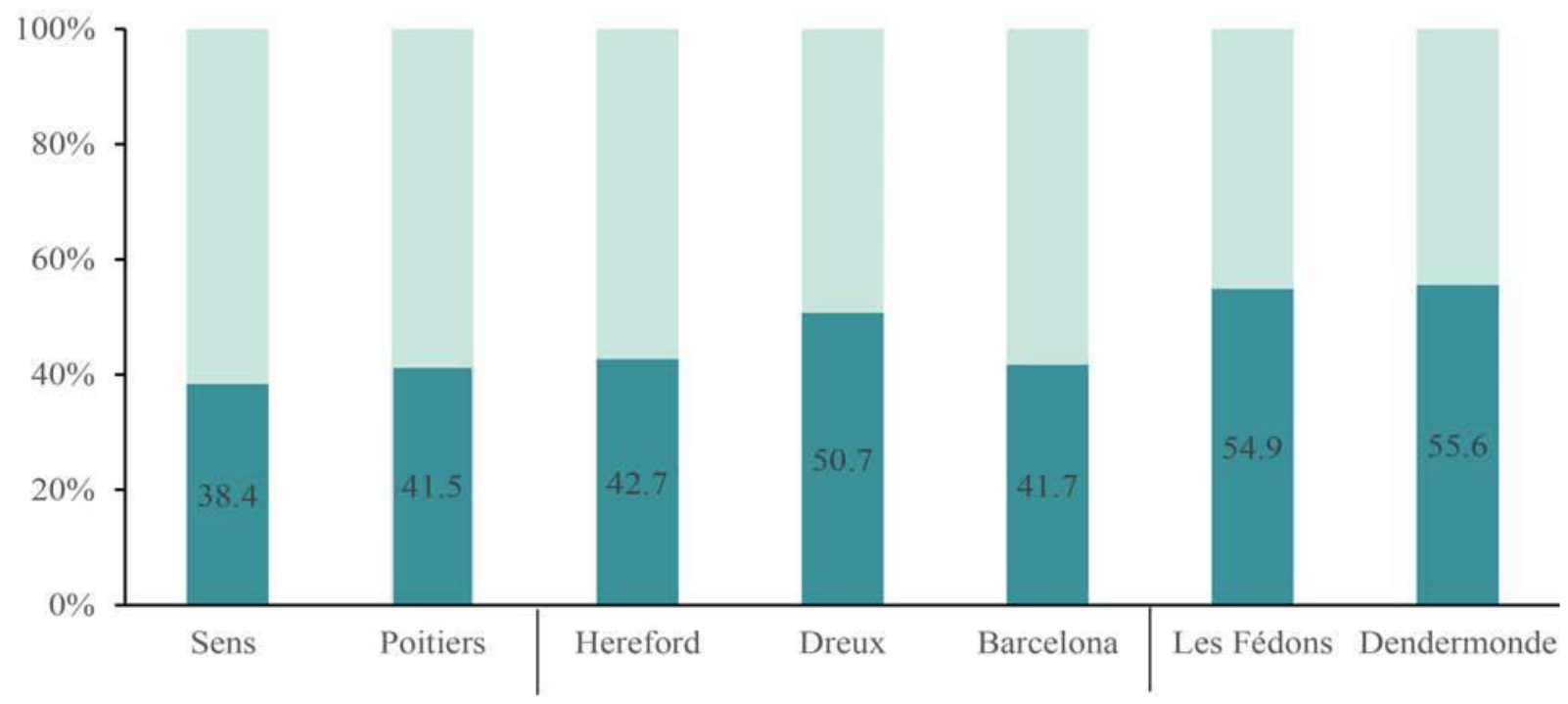

6th c.

14th c.

16th c.

Fig. 4. Distribution of ages at death for immature subjects. Comparisons with theoretical values of Ledermann (1969): Justinian's plague, 6th century (a); Black Death, $14^{\text {th }}$ century (b); resurgences, 16th century (c).
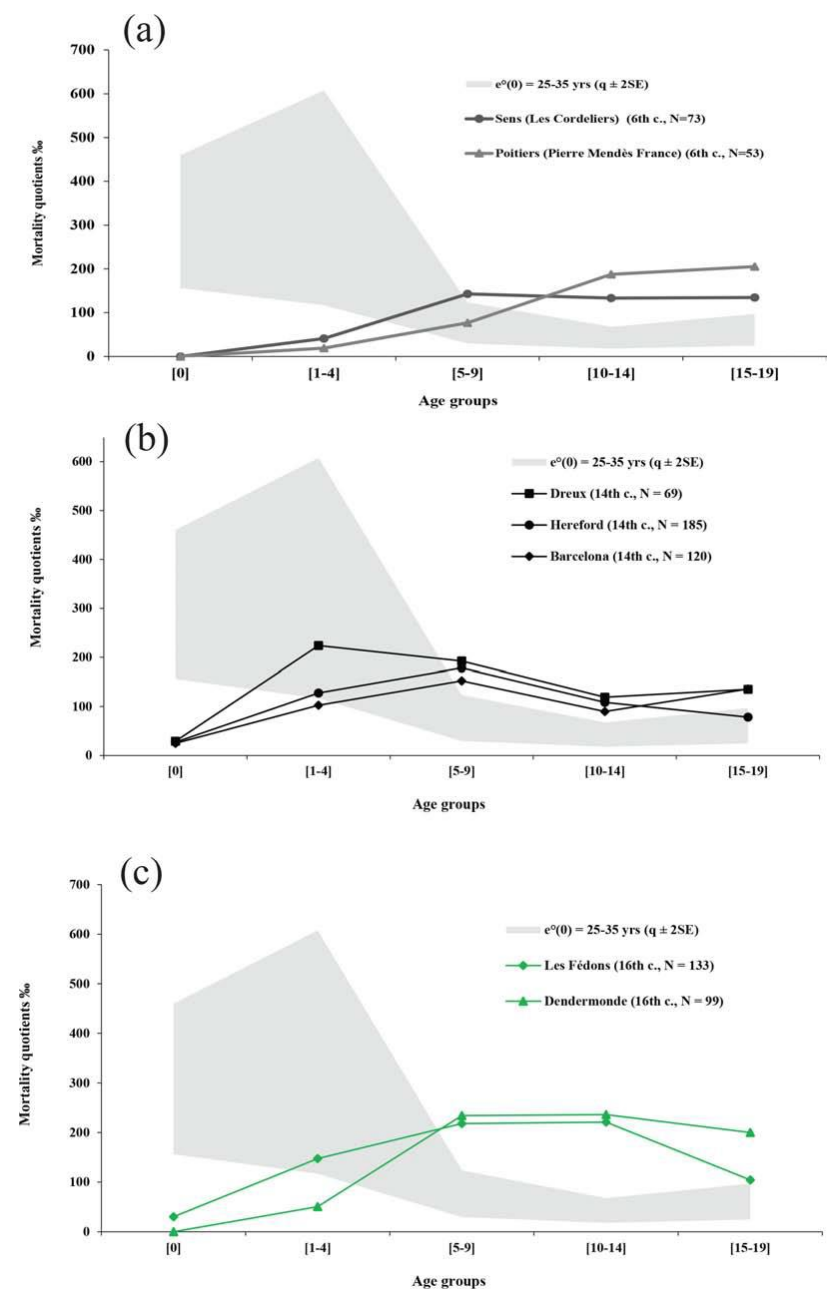
Fig. 5. Adult sex distribution for each plague site. Sex ratio of the Barcelona sample is unknown due to the low number of sexed individuals.

Males Females

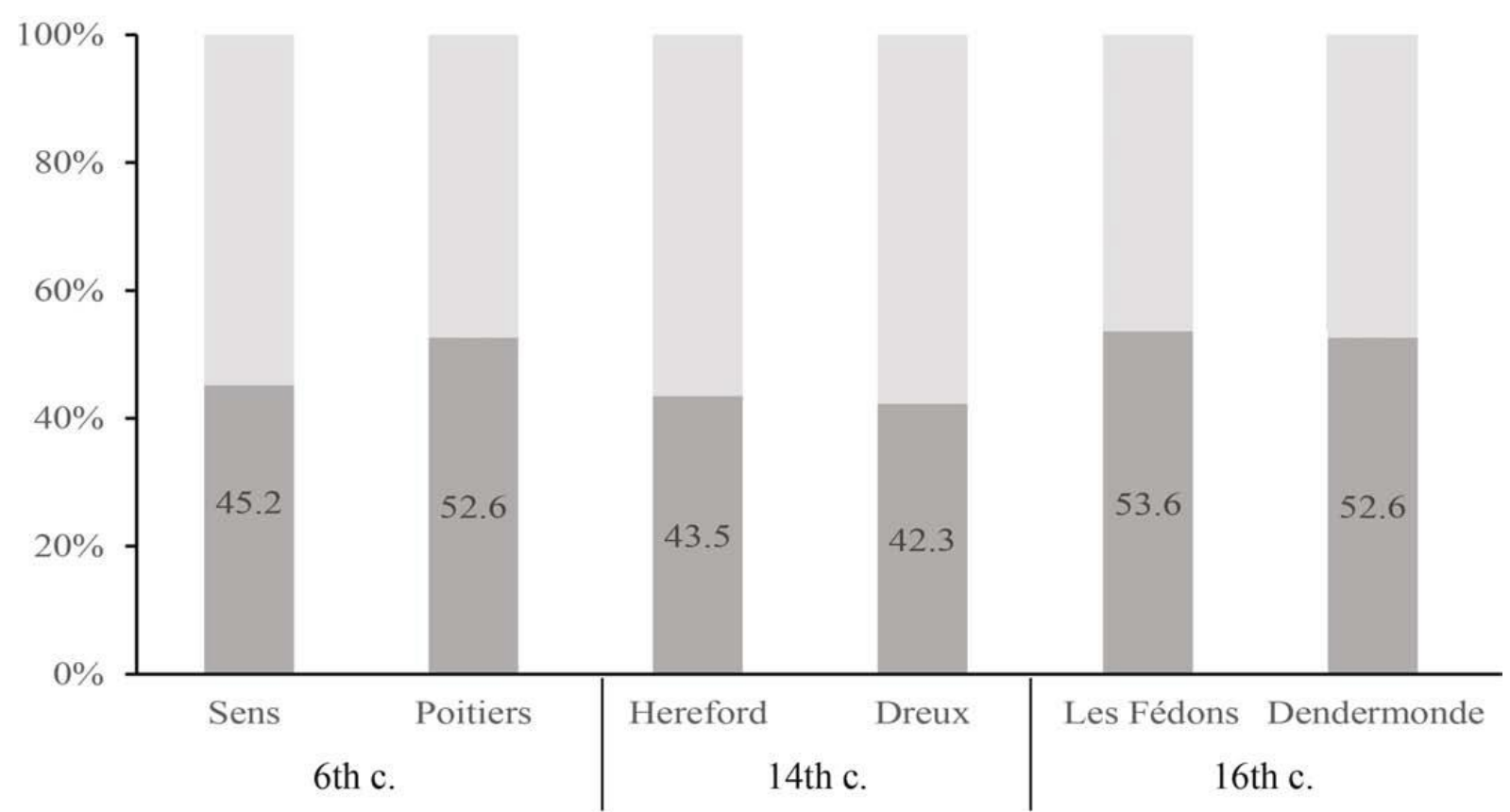

Table 1. Demographic data (number of individuals, age, sex, mortality quotients, juvenility index) for each plague site.

\begin{tabular}{|c|c|c|c|c|c|c|c|c|c|c|c|c|c|c|}
\hline & \multicolumn{2}{|c|}{ Sens } & \multicolumn{2}{|c|}{ Poitiers } & \multicolumn{2}{|c|}{ Hereford } & \multicolumn{2}{|c|}{ Dreux } & \multicolumn{2}{|c|}{ Barcelone } & \multicolumn{2}{|c|}{ Les Fédons } & \multicolumn{2}{|c|}{ Dendermone } \\
\hline & $\mathrm{N}$ & $a Q x$ & $\mathrm{~N}$ & $a Q x$ & $\mathrm{~N}$ & $a Q x$ & $\mathrm{~N}$ & $a Q x$ & $\mathrm{~N}$ & $a Q x$ & $\mathrm{~N}$ & $a Q x$ & $\mathrm{~N}$ & $a Q x$ \\
\hline 0 & 0 & 0 & 0 & 0 & 5 & 27,03 & 2 & 28,99 & 3 & 25,00 & 4 & 30,08 & 0 & 0 \\
\hline $1-4$ & 3 & 41,10 & 1 & 18,87 & 23 & 127,78 & 15 & 223,88 & 12 & 102,56 & 19 & 147,29 & 5 & 50,51 \\
\hline $5-9$ & 10 & 142,90 & 4 & 76,92 & 28 & 178,34 & 10 & 192,31 & 16 & 152,38 & 24 & 218,18 & 22 & 234,04 \\
\hline $10-14$ & 8 & 133,30 & 9 & 187,50 & 14 & 108,53 & 5 & 119,05 & 8 & 89,89 & 19 & 220,93 & 17 & 236,11 \\
\hline $15-19$ & 7 & 134,60 & 8 & 205,13 & 9 & 78,26 & 5 & 135,14 & 11 & 135,80 & 7 & 104,48 & 11 & 200,00 \\
\hline Efectif total & \multicolumn{2}{|c|}{73} & \multicolumn{2}{|c|}{53} & \multicolumn{2}{|c|}{185} & \multicolumn{2}{|c|}{69} & \multicolumn{2}{|c|}{120} & \multicolumn{2}{|c|}{133} & \multicolumn{2}{|c|}{99} \\
\hline 20 et + & \multicolumn{2}{|c|}{45} & \multicolumn{2}{|c|}{31} & \multicolumn{2}{|c|}{106} & \multicolumn{2}{|c|}{32} & \multicolumn{2}{|c|}{70} & \multicolumn{2}{|c|}{60} & \multicolumn{2}{|c|}{44} \\
\hline D5-14 / D20+ & \multicolumn{2}{|c|}{0,4} & \multicolumn{2}{|c|}{0,42} & \multicolumn{2}{|c|}{0,4} & \multicolumn{2}{|c|}{0,47} & \multicolumn{2}{|c|}{0,37} & \multicolumn{2}{|c|}{0,72} & \multicolumn{2}{|c|}{0,89} \\
\hline
\end{tabular}

